\title{
Evolution of Banking Mergers and Acquisitions Market in Russia
}

\author{
Submitted 20/01/19, 1st revision 23/02.19, 2nd revision 30/04/19, accepted 15/06/19 \\ Penyugalova A.V. ${ }^{1}$, Platonova Yu.Yu. ${ }^{2}$, Pyshnogray A.P. ${ }^{3}$, \\ Samsonenko V.A. ${ }^{4}$
}

\begin{abstract}
:
Purpose: The article characterizes efferent and afferent trends as a strategic factor in the evolution and development of the banking system of the Russian Federation.

Design/Methodology/Approach: The article reveals the peculiarities of the processes of mergers, takeovers, and acquisitions taking place in the Russian market, emphasizes their evolutionary and cyclical nature, making a conclusion about the optimization of existing business processes, the transition to a market-oriented way of managing capital.

Results: The phenomenon of bank mergers and acquisitions is another step in the evolution of financial capital. This process should be considered against the background of the development of the entire industry of financial markets associated with the organization of new institutions and extinction of outdated forms of organization of redistributive processes.

Practical implications: Solving number of tasks related to the optimization of existing business processes, the transition to a market-oriented way to manage capital are critically important for the successful restructuring of the financial architecture under the pressure of new technological challenges for domestic banks. Slowdowns in these processes will lead to the need to tackle cross-cutting tasks, which will create risks for providing financial resources for the entire economy.

Originality/Value: Prospective systemic changes in the banking sector of Russia will also affect the sphere of mergers, while the processes will simultaneously move in several directions. The institutions who failed to restructure business processes in a new technological environment will have to leave the market due to the outflow of customers.
\end{abstract}

Keywords: Commercial banks, Russian market of banking mergers and acquisitions.

JEL Codes: D30, D39.

Paper Type: Research article in a Special Issue dedicated to Russian Economy.

Section 8: Business and Economic Issues.

\footnotetext{
${ }^{I}$ D.Sc., Professor, Kuban State University, Krasnodar, Russian Federation, penugalova@mail.ru

${ }^{2}$ Ph.D., Associate Professor, Kuban State University, Krasnodar, Russian Federation, 9615838050@mail.ru

${ }_{3}^{3}$ Ph.D., Associate Professor, Kuban State University, Krasnodar, Russian Federation, mpregen@inbox.ru

${ }^{4}$ Lecturer, Kuban State University, Krasnodar, Russian Federation, valentinkasam@mail.ru
} 


\section{Introduction}

The phenomenon of bank mergers and acquisitions is another step in the evolution of financial capital. This process should be considered against the background of the development of the entire industry of financial markets associated with the organization of new institutions and extinction of outdated forms of redistributive processes organization in society. Thus, the post-war period in fact was marked by the flourishing of this industry in the US market, which is associated with the rapid growth of the economy as well as the stock and insurance markets (Alhadeff, 1955; Tachmatzidi, 2018; 2019).

The game rules in the financial market during that period underwent significant changes. It was the norm to consider players representing various segments as competitors in the struggle for large customers. The restrictions at that time, for example, the "ten percent" rule for bank lending, could not affect the rapid growth of the market for mergers and acquisitions, as well as the aggregate increase in bank assets. The historical experience accumulated over the entire post-war period of development of the financial industry shows that a positive economic effect could be achieved only in conditions of balanced development of all segments of the financial services market, which allows, ultimately, meeting the financial needs of the economy.

In other studies, the identified patterns are generally confirmed. It is noted that the positive effect of mergers and acquisitions, mainly manifested in lower interest rates, is observed in highly competitive segments of bank lending, while transactions associated with monopolization of markets lead to an increase in the gaps between the levels of interest rates that existed before decisions on mergers and acquisitions. Notable the importance for the banking services market of the emergence of new technologies for assessing the creditworthiness of borrowers (scoring models) at the beginning of the two thousand years. The effect was the lowering interest rates on the one hand, and on the other, it provided the ground for further unification and convergence of service standards, which significantly simplified business combinations and led to an increase in the concentration of capital in the banking market (Erel, 2011).

\section{Key Factors and Trends of Mergers and Acquisitions of Credit Institutions in Russia}

The state owns more than a half in the share capital of the largest domestic banks. Sberbank, VTB, Bank of St. Petersburg, Moscow Credit Bank are among the free equity banks. At the same time, free float levels vary significantly. Sberbank's 
minority and unidentified investors account for $47 \%$ of the capital, in VTB and Bank St. Petersburg, the value is about 20\%, in Moscow Credit Bank it is less than $15 \%$.

Scenarios with pure market acquisitions that take into account the capitalization of a business, profitability, and other investment indicators are substantially limited. In addition, approval is required from the regulator and the antimonopoly service. In fact, this means that the market is closed for intensive capital flows accompanied by a change of major shareholders. It is important to identify the interests of the state in the ownership structure of the backbone banks. Table 1 presents the assets of the ten largest banks in Russia.

Table 1. Leaders of the Russian banking market in 2018 (Expert RA, 2018)

\begin{tabular}{|l|l|c|c|}
\hline No & \multicolumn{1}{|c|}{ Bank } & $\begin{array}{c}\text { Volume of assets, } \\
\text { billion rub. }\end{array}$ & State capital share, \% \\
\hline 1 & Sberbank & 23806,1 & 52,3 \\
\hline 2 & VTB & 9808,4 & 60,9 \\
\hline 3 & Gazprombank & 5530,5 & over 50 \\
\hline 4 & VTB24 & 3737,4 & 69,1 \\
\hline 5 & Rosselkhozbank & 3222,6 & 100,0 \\
\hline 6 & NCC & 2782,0 & 25,0 \\
\hline 7 & Alfa-Bank & 2647,8 & 0,0 \\
\hline 8 & Otkrytie & 2004,5 & 99,9 \\
\hline 9 & Moscow Credit Bank & 1872,9 & 0,0 \\
\hline 10 & Promsvyazbank & 1233,0 & 99,9 \\
\hline & Total & 56645,1 & 54,5 \\
\hline
\end{tabular}

Thus, the state accounts for over $50 \%$ of the total assets of the ten largest banks in the domestic economy, in which $66 \%$ of the assets of the entire banking industry are concentrated. This situation needs to be considered in two ways: on the one hand, the concentration of resources allows quickly redirecting capital flows between industries and territories, solving various socio-economic problems.

A similar situation is observed in the largest developing economies. Thus, three out of the ten largest banks in Brazil, specializing in social and infrastructure projects, are fully or partially state owned. The four largest banks in China also have a significant share of the state in their capital. The downside is the low efficiency of the banks, which will affect the capitalization of the business.

In fact, in modern Russia, a model has emerged in which the cash flows generated in the banking industry have become a priority in relation to business growth. Regular financial support from the state over the past ten years significantly reduces the motivation to provide organic business growth (even partially exempt from responsibility for the results of operations) (Table 2). 
Table 2. Financial performance of major Russian banks (Expert RA, 2018)

\begin{tabular}{|l|l|c|c|}
\hline No. & \multicolumn{1}{|c|}{ Bank } & $\begin{array}{c}\text { Financial result, } \\
\text { billion rub. }\end{array}$ & State capital share, $\%$ \\
\hline 1 & Sberbank & 684,5 & 52,3 \\
\hline 2 & VTB & 124,2 & 60,9 \\
\hline 3 & Gazprombank & 40,8 & over 50 \\
\hline 4 & VTB24 & 0,0 & 69,1 \\
\hline 5 & Rosselkhozbank & 0,5 & 100,0 \\
\hline 6 & NCC & 16,8 & 25,0 \\
\hline 7 & Alfa-Bank & 49,7 & 0,0 \\
\hline 8 & Otkrytie & $-242,2$ & 99,9 \\
\hline 9 & Moscow Credit Bank & 12,9 & 0,0 \\
\hline 10 & Promsvyazbank & 8,6 & 99,9 \\
\hline
\end{tabular}

Private banks in the Top-10 in terms of assets have a positive financial result, while Gazprombank, the National Clearing Center (NCC) and Promsvyazbank, whose results are generally comparable, could be distinguished from a group of banks with a significant state share.

The complexity of the financial state of one of the structural units of the VTB Group (VTB24), Rosselkhozbank and Otkrytie is largely due to non-market factors in the activities of companies. But if the importance of financial support for the agricultural industry is objectively necessary, and losses of past years, as well as poor performance in 2017 as a whole, could be presented as exceptional measures of state support for the industry, then the Otkrytie's portfolio is overflowed with toxic assets, the origin of which and their future remains subject to non-economic forms of capital movement.

Ultimately, the financial support of suspicious transactions will be a burden of the regulator, which essentially is the loss of financial resources of industries and territories that need lending. The current situation exactly corresponds to the concept of S.G. Kordonsky (2010) in which the development of resources pursues a goal that includes the implementation of a set of socio-economic, financial and other tasks. Poor efficiency of banks is essentially a payment for the resources provided, and the result must be sought in the gain of lending of low-profit agriculture, small businesses, etc. Investment attractiveness for such banking structures is supported by government, the purchase of shares by minority shareholders is not even technically foreseen, but debt investments are a relatively stable investment object.

The situation with mergers and acquisitions in similar banks is somewhat different. There are no competitors in state banks, but competition exists at the level of 
distribution of state (federal, regional, etc.) resources. In such a framework, any decrease of the amount of funds provided inevitably leads to financial difficulties, which ultimately serves as a basis for mergers, acquisitions or other forms of reorganization of activities (Rybin, 2007)

The movement of assets in such structures is not so much related to objective market necessity, since the source of resource replenishment is able to financially compensate for inefficient managerial decisions. In the hierarchy of objectives, the cash flows are higher than the capitalization of the business, as the gradual privatization of the profitable division would allow extracting significantly more funds, while the synergistic effect of the merger did not actually affect the capitalization of the whole VTB Group.

There is a unique situation - business reorganization with the restructuring of the entire service architecture, replacement of accounts, an increase in assets of more than $38 \%$, in fact, had no effect on the growth of business capitalization. Such practices have ceased to be phenomena, that is, the market has developed a strategy for passive observation of decisions taken by structures with state participation. Mergers and acquisitions in such systems serve the purpose of optimizing cash flows with the subsequent development of resources.

The flagship of the domestic banking industry is Sberbank, whose share is just under 30\% of the total assets of the entire system of commercial banks. For several years, Sberbank has remained the leader of the economy in terms of its profits, and technological solutions embedded in business processes allow updating and optimizing the entire service delivery system, which leads to an increase in credit availability and expands access to economic entities to other financial instruments. The most important criterion for the success of Sberbank's operations is its market capitalization, which over the last ten years has increased several times (Figure 1).

Figure 1. Sberbank share price dynamics (CBRF, 2018)

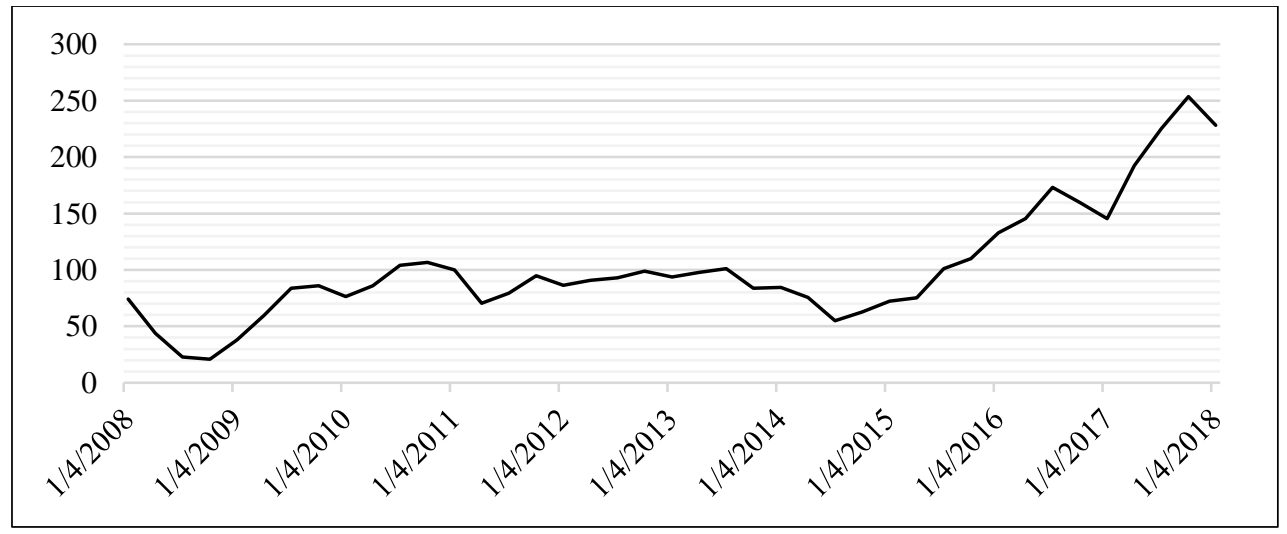


The formed Sberbank Asset Management division remains the leader in the Russian market of collective investment and trust management in terms of the volume of attracted funds and the value of net assets. In addition to this transaction, we note the acquisition of Turkish DenizBank in 2012. These investments allowed consolidating the presence in a large market and consistently make a profit. The success of Sberbank consists in market capitalization, albeit regarding overall undervalued state of the domestic stock market. Over the past five years, Sberbank shares remain the most liquid among blue chips, and the daily turnover is over thirty billion rubles.

The capitalization dynamics for the same period of the second largest player in the banking market is presented in Figure 2. The situation on the Russian market demonstrates the impossibility of selecting universal models for analyzing the effectiveness of mergers and acquisitions decisions in the banking market. If we apply the approach of R. Bruner, then the role of institutional investors will have to be the board members of VTB Bank, whose management decisions provide "wealth destruction" (Bruner, 1999).

Figure 2. VTB share price dynamics (CBRF, 2018)

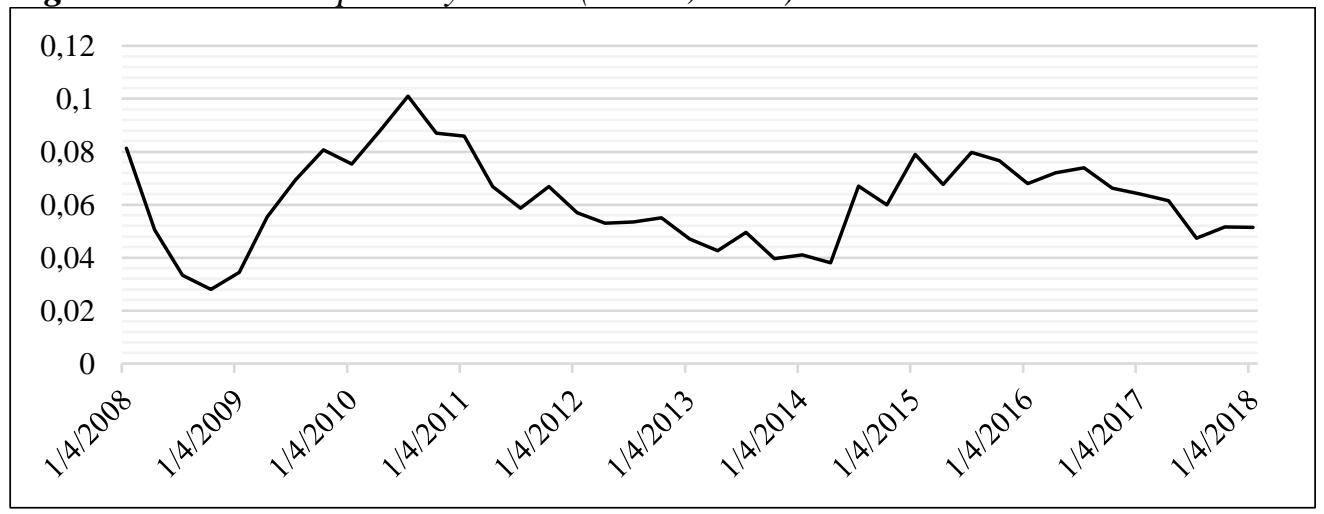

The hypothesis of low-efficiency public administration cannot be considered wealthy, since the two largest financial corporations with a similar capital structure turn out to be in a polar ratio by the market efficiency criterion. The likely reason for the differences is the approach to coordinating interests: $20.7 \%$ of VTB's capital is in the hands of minority shareholders, while Sberbank's share capital structure assumes regular dividend payments on preferred shares, $56 \%$ of which are owned by nonresidents.

In addition, non-resident legal entities own a stake of over $45 \%$. Investment attractiveness and the need to work on the growth of capitalization and profitability of investments in Sberbank actually shifts business processes into operation mode, in which the growth of business value is not a goal, but a condition of survival. 
Further development of financial and credit sphere and the banking services market will inevitably lead to the abandonment of inefficient management models. Concentration of bank capital, mergers and acquisitions should be brought to a common target denominator, since financial losses as a result of recapitalization procedures, inaccessibility of long-term loans, high interest rates significantly inhibit the financing of economic growth. In an environment where the market price of a business structure is not fixed online at trades with a large number of private independent investors, the processes of mergers and acquisitions (as the highest degree of capital concentration) lack the grounds, and the decisions made serve the resource-oriented forms building a business, not the consensus of stakeholder groups.

Moscow exchange offers a wide range of analytical tools to make investment decisions. Thus, in the index of shares of financial companies, out of 547 operating credit institutions, four credit and one investment company are included. There are no other equity securities of banks in the market. It follows why the market did not respond to the merger of VTB 24 to VTB - the total balance will be increased by the amount reduced by the authorized capital of VTB24.

Subsequently, probably not solely for this reason, Sberbank turned out to be the most successful corporation of the entire top-tier domestic business. If we estimate the depth of invasion of foreign players into the Russian banking market, then any foreign banks are missing in the top ten largest banks list. Leaders in total assets are presented in table 3.

Table 3. The largest banks with foreign capital in 2018 (Expert RA, 2018)

\begin{tabular}{|l|l|c|c|}
\hline No. & \multicolumn{1}{|c|}{ Bank } & $\begin{array}{c}\text { Volume of assets, } \\
\text { billion rub. }\end{array}$ & $\begin{array}{c}\text { Financial result, } \\
\text { billion rub. }\end{array}$ \\
\hline 1 & Unicredit Bank & 1218,6 & 30,5 \\
\hline 2 & Rosbank & 957,8 & 4,2 \\
\hline 3 & Raiffeisen Bank & 879,6 & 22,9 \\
\hline 4 & Citibank & 471,3 & 15,0 \\
\hline 5 & Vostochny Bank & 273,6 & 4,9 \\
\hline 6 & HomeCredit Bank & 262,2 & 11,8 \\
\hline 7 & Nordea Bank & 174,0 & 4,1 \\
\hline 8 & Delta Credit & 173,3 & 1,7 \\
\hline 9 & ING Bank & 170,0 & 3,0 \\
\hline 10 & OTP Bank & 137,3 & 2,4 \\
\hline & Total & 4717,7 & 100,5 \\
\hline
\end{tabular}

The share of the ten largest foreign players in the Russian banking market in terms of assets is $5.5 \%$, which is certainly far from the category of dominance, but it should be noted that the domestic industry leaders are ahead of foreign institutions in terms of the ratio of assets and financial results. It is important to note that for most foreign 
players, the share capital of the parent structures is dispersed among minority shareholders and institutional investors. For example, the largest shareholder of the UniCredit group owns a share of less than 6\%, while Societe Generale has a 74\% stake in free float, management and employees own $10 \%$ of the shares.

Regarding the forecast on the mergers of Russian financial institutions by foreign players, there is also no incarnated sustainable trend. Blocks of securities owned by foreign players make possible extracting a small current yield, a systemic increase in capitalization is observed only in Sberbank. In this regard, we can conclude that the expansion of foreign players in various forms into the Russian market does not lead to the loss of independence of the banking and credit system, the fears of the scientific mainstream of the post-Soviet economic school were not justified in general.

Financial globalization has been developing somewhat differently in the domestic realities: a systemic dependence on credit resources has been established in the world markets of the largest domestic banks. Currently, there are nine issues of Sberbank bonds with an aggregate issue volume of over $\$ 9$ billion on global platforms. The sanctions imposed significantly restricted access to world capital markets, where it was possible to attract low-interest resources.

Thus, the weighted average coupon rate of the last thirteen issues of Sberbank Eurobonds was $5.12 \%$. For comparison, in the Russian debt market coupon rates are higher for federal loan bonds. Thus, non-mergers and acquisitions of national credit institutions with foreign capital predetermine the risks of financial globalization. The overlapping of access to the liquidity of world sites turns out to be the most sensitive area. The price that Sberbank and the VTB Group are willing to pay to receive foreign loans - is the loss of the market with two million private clients and thirty thousand enterprises and organizations.

\section{Conclusion}

The opportunities offered by the introduction of fintech developments are not just innovative. This is a really quiet revolution, as evidenced by the explosive leap on the cryptocurrency market in recent years, as well as announced robotization programs in the provision of financial services, which will lead to the lay off of 2 million workers in the banking industry in the US and Europe, according to analysts of Citigroup. System transformations will also affect the field of mergers of the banking business, while the processes will simultaneously move in several directions. The institutions that have failed to restructure business processes in a new technological environment, will have to leave the market due to the outflow of customers.

The solution of several tasks related to the optimization of existing business processes, the transition to a market-oriented way to manage capital is still critically important for the successful restructuring of the financial architecture under the pressure of new 
technological challenges for domestic banks. Slowdowns in these processes will lead to the need to tackle cross-cutting tasks, which will create risks for providing financial resources for the entire economy.

\section{References:}

Alhadeff, Ch., Alhadeff, D. 1955. Recent Bank Margers. The Quarterly journal of Economics, 4(69), 503-532.

Bruner, R.F. 1999. An analysis of Value destruction and recovery in the alliance and proposed merger of Volvo and Renault. Journal of Financial Economics, 51, 125166.

CBRF. 2018. Official website of the Central Bank of Russia. Available at: www.cbr.ru

Erel, I. 2011. The Effect of Bank Mergers on Loan Prices: Evidence from the United States.

The Review of Financial Studies, 4, 1068-1101.

Expert RA. 2018. Expert rating agency. Available at: https://raexpert.ru

Kordonsky, S. 2010. Russia. The Manor Federation. Moscow, Europa publishing, 312.

Rybin, E.V. 2007. Mergers and acquisitions of banks in Russia as a factor in the expansion of foreign banking capital. Money and credit, 3, 37-42.

Tachmatzidi, I. 2018. Takeover Defenses in the United Kingdom. International Journal of Economics \& Business Administration, 6(4), 105-118.

Tachmatzidi, I. 2019. Comparative Analysis of Takeover Defenses in Strong and Weak Economies: The Paradigm of the UK and Greece, European Research Studies Journal, 22(2), 254-264. 